\title{
Experimental Studies on the Steroid Aromatization
}

Appendix: On the aromatization of $17 \alpha$-methyl-steroids

\author{
Minoru AMATSU \\ Department of Obstetrics and Gynecology, Kyoto Prefectural University of Medicine \\ (Director : Prof. Gen-ichi Tokuda)
}

In the previous paper, aromatization of dehydroepiandrosterone, 4-androstenedione and testosterone was reported. In this paper, two $17 \alpha$-methyl-steroids were studied about the possibility of their aromatization in vitro.

Methods were similar to those described in the previous paper, but $17 \alpha$-methyl19-nortestosterone and $17 \alpha$-methyl-testosterone were used as substrate. Phenolic extract obtained in 8 experiments with $17 \alpha$-methyl-19-nortestosterone was pooled and chromatographed on paper in the benzene-ligroin-methanol-water system for 4 hours at $25^{\circ} \mathrm{C}$.

Areas corresponded in its mobility with authentic $17 \alpha$-methyl-estradiol were eluted by methanol and rechromatographed several times in the same system.

The compound thus obtained was compaired with authentic $17 \alpha$-methyl-estradiol in its UV-absorption spectrum, sulfuric acid chromogen spectrum, alcohol-sulfuric acid (1:2) chromogen spectrum, and $2 \%$ hydroquinone-65\% sulfuric acid chromogen spectrum. All these findings revealed, the compound obtained in the incubation of $17 \alpha-$ methyl-19-nortestosterone with human placental homogenate was $17 \alpha$-methyl-estradiol.

Experiments with $17 \alpha$-methyl-testosterone also resulted the formation of $17 \alpha$-methylestradiol in the same criteria.

(pp. 1009-1012) 


\title{
Steroid Aromatization に関する実験的研究
}

\author{
〔続報〕 \\ 京都府立医科大学産婦人科学教室（主任 徳田源市教授） \\ 天 津
}

（昭和38年11月28日受付）

緒

言

著者はすでに胎艋の steroid aromatizing enzyme system ${ }^{1}$ を老用いて dehydroepiandrosterone， $\Delta_{4}$-androstene-3, 17-dione, testosterone および各種合成 progestin の estrogen への転換の可能性につき検討を加 え報告した ${ }^{2}$. しかし $17 \alpha$ 位に methyl 基を有する testosterone および 19-nortestosterone の諗導体であ る 17 $\alpha$-methyl-testosterone [以下 MT と略〕および $17 \alpha$-methyl-19-nortestosterone [以下 MNT と略] を substrate として行なった実験では，estronefraction に Hydroquinone-Kober 第 1 反応で黄色を呈し加熱 時間の経過と共に祓色をはじめ，第 2 反応後はほとんぞ chromogen を形成しない物質の存在を認めて報告 した. このものが 17 $\alpha$-methyl-estradiol [以下 MED と略]であるかどうかけついては MED の pure sample が入手困難であつたので決定出来なかつた．しかし今回幸いに MEDの pure sample を入手し得たのでて の点につき検討を試みて，前述の Hydroquinone-Kober 第 1 反応で黄色を呈する物質が MED であるとと を確認し得たので報告する.

\section{実 験 方 法}

婏出直後の胎盤から大血管および卵膜を除きてれを $0.05 \mathrm{~mol}$ phosphate, $\mathrm{pH} 7.0,0.04 \mathrm{~mol}$ nicotinamide を含んだ $0.25 \mathrm{~mol}$ sucrose 溶液（incubation medium）で 1 回洗滌，水分を可及的に除き，鉄で細切後 waring blender で homogenize し, その $20 \mathrm{~g}$ ずつを計量した. 次に上記の incubation menium $7 \mathrm{ml}$ を加光ふたたび homogenize し，てれに substrate として今回はMNT お よびMT各々 $500 \mu \mathrm{g}$ を propylene glycol $0.2 \mathrm{ml}$ 亿溶解して加え, gasphose を空気と して 2 時間 incubation した. Incubation は 同時に 8 個を行ない pool した。

組織からの抽出には acetone を用い以後 の抽出精製操作は Table 1 のよう亿 Engel 法年4)を改良して行なつた．次に内径 $7 \mathrm{~mm}$ のガラス管に Brockmann alumina Oxydatum standard 活性度 II-III $2.0 \mathrm{~g}$ を充填 し， benzene $5 \mathrm{ml}$ で資料を吸着させて $5 \%$ methanol-benzene $30 \mathrm{ml}$ で MED-fraction を溶出した。乙の後 benzene-ligroin-methanol-water system $[70: 130: 160: 40]$ K

Table 1. Extraction and Purification of Estrogens.

Placenta $20 \mathrm{~g}$ wet weight homogenate Extracted with Acetone $60 \mathrm{ml} 3$ times Aqueous phase extracted with Ether $50 \mathrm{ml} 3$ times Evaporated to $5 \mathrm{ml}$

Petroleum-ether $50 \mathrm{ml}$ added

Extracted with $\mathrm{IN}-\mathrm{NaOH} 10 \mathrm{ml} 3$ times

Acidified to $\mathrm{pH} 7.0$ with conc. HCl

Extracted with Ether $50 \mathrm{ml} 3$ times Washed with $5 \%-\mathrm{NaHCO}_{3}$ and dist. Water

Evaporated to dryness

Dissolved in Toluene $50 \mathrm{ml}$

Extracted with IN-NaOH $10 \mathrm{ml} 3$ times

Acidified to $\mathrm{pH} 7.0$ with conc. HCl

Extracted with Ether $50 \mathrm{ml} 3$ times

Washed with dist. Water

Evaporated to dryness

Alumina Golumn Chromatography

Paper Chromatography 
Fig. 1. Hydroquinone- $\mathrm{H}_{2} \mathrm{SO}_{4}$ chromogen spectra of MED, and Hydroquinone-Kober chromogen spectra of MED obtained from incubation of MNT and MT

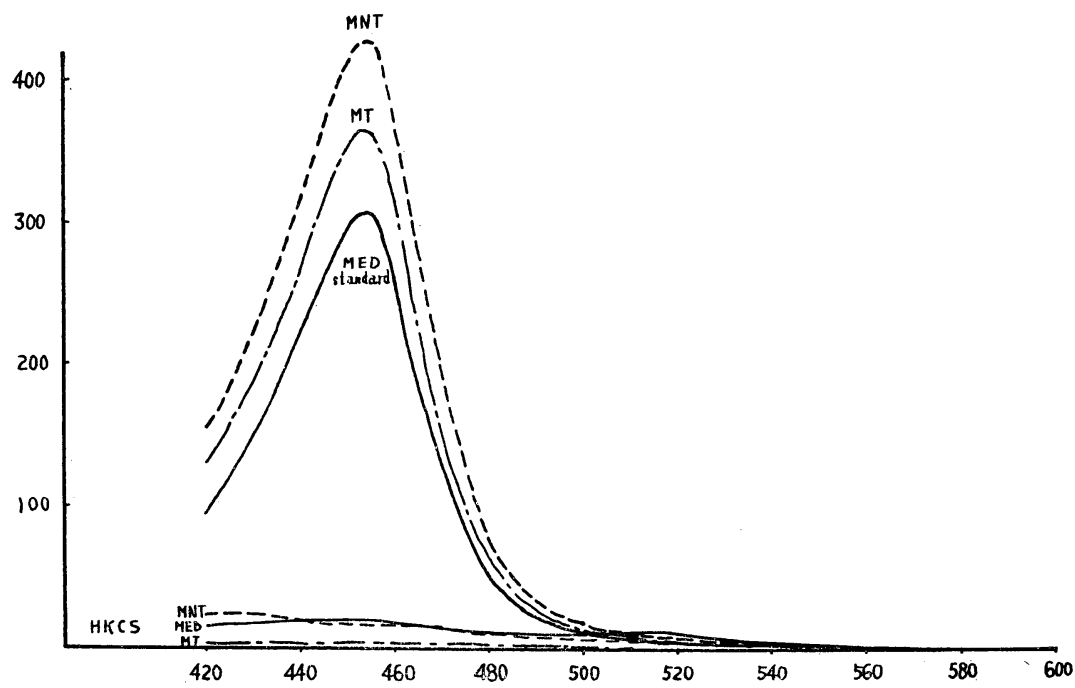

よる paper chromatographyを施行して standard の MED 相当部分を methanol で 溶出後, さらに 2 回の rechromatography 行ない各種の定性反応に供した。

\section{実験成績ならびに考察}

\section{Hydroquinone-Kober 反応}

すでに報告したとおり MNTおよび MT を substrate として incubation を行なつて 得られた抽出物に Hydroquinone-Kober 反 応を行なうと Hydroquinone 硫酸を加えた のみで黄色を呈する。その chromogen spectrum はFig.1 に示すように $455 \mathrm{~m} \mu$ に peak を有する。乙の呈色は加熱により一時 増強するがのち漸次裉色をはじめ，第 2 反応 終了後にはほとんど chromogen を形成しな くなる。

standard MED そついて同時に Hydroquinone-Kober 反応を行なつても第 1 反応 加熱前の chromogen spectrum は同様の peak を示し，第 2 反応終了後にはほとんど chromogen を形成しなかつた。

\section{Paper chromatography}

MNTおよびMTの incubation で得られ た抽出物を前述の system により展開し， paper 上での発色は Burton ${ }^{5}$ の報告した $1 \%$
Fig. 2. Paper chromatogram of MED obtained from incubation of MNT

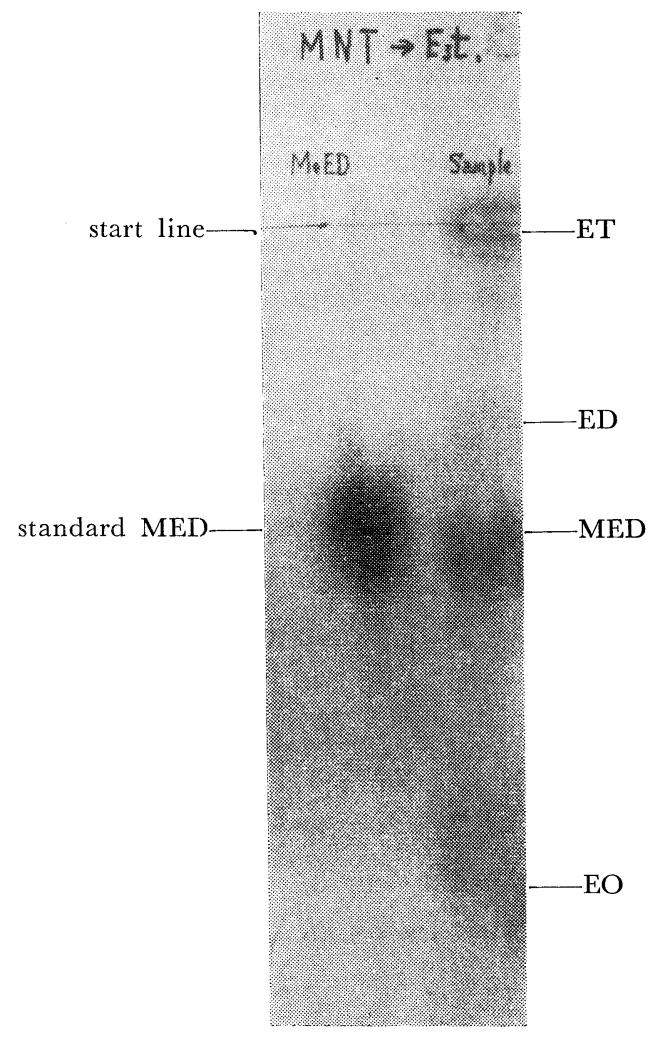


$\mathrm{FeCl}_{3}$ と $1 \% \mathrm{~K}_{8} \mathrm{Fe}(\mathrm{CN})_{6}$ の等量混合液を用いて行なつた. Fig.2 に示したように substrate として MNT, MTのいずれを用いても standard MEDのRfと合致する spot を得た。なお MEDのRfは0.34である.

3 Ultraviolet absorption spectrum

さらに同一 system そよる 2 回の rechromatography ののちに ethanol 中での ultraviolet absorption spectrum を測定した. Fig.3 に示したようにMNTおよびMTいずれを substrate とした場合にもその抽 出物は aromatic 3-hydroxy steroid に特有である $280 \mathrm{~m} \mu$ 付近に peak が認められ， standard MED のそ れと一致した.

Fig.3. UV-absorption spectra of MED obtained from incubation of MNT and MT
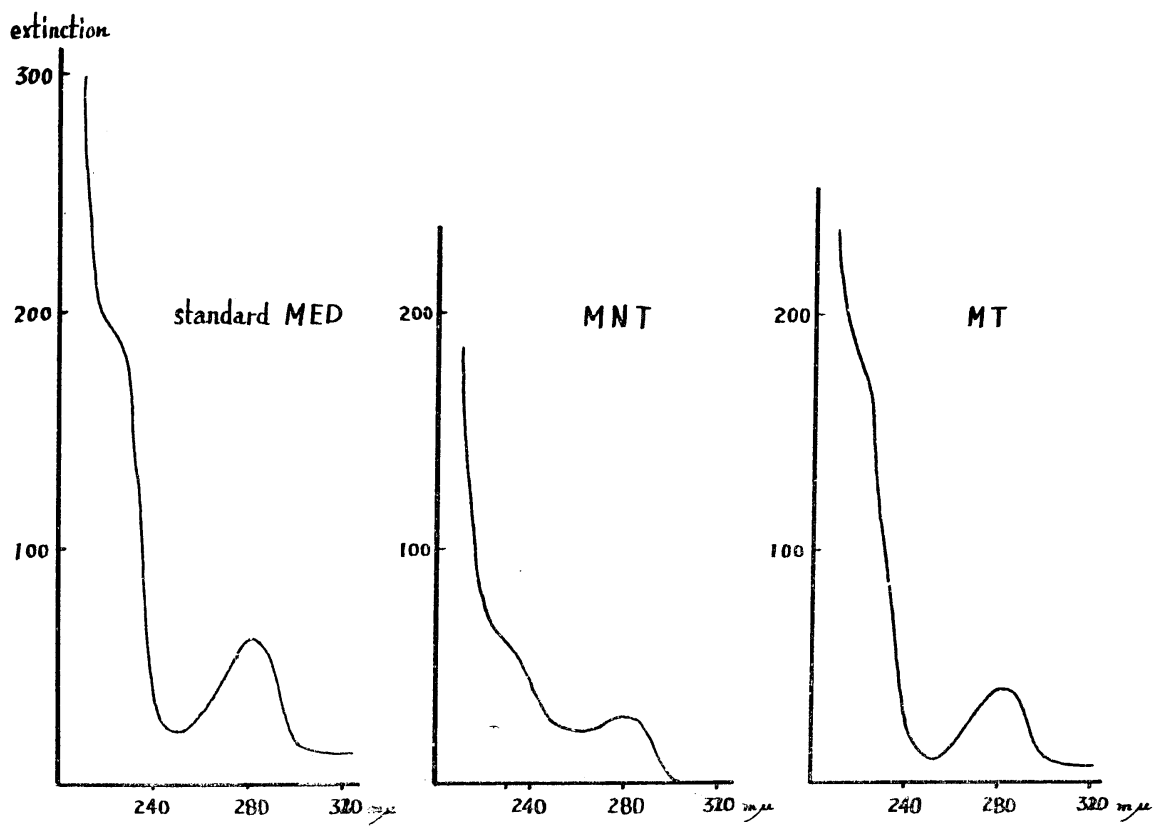

Fig.4. Sulfuric acid chromogen spectra of MED obtained from incubation of MNT and MT

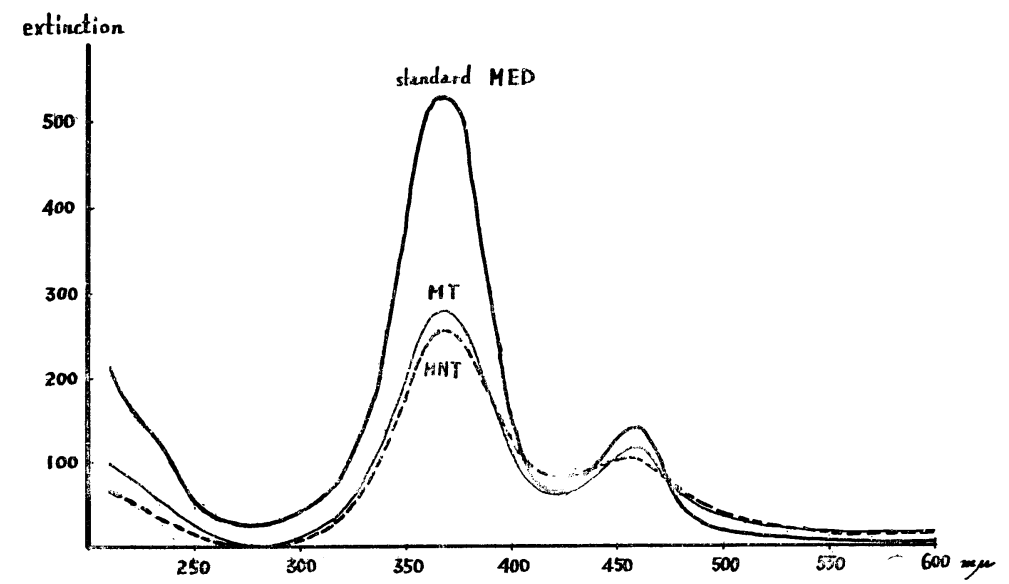

第39巻 第11号 


\section{Sulfuric acid chromogen spectrum}

硫酸 $4 \mathrm{ml}$ を加え室温に 2 時間放置してその chromogen spectrum を测定した. Fig. 4 に示すように MNT, MTのいずれを substrate とした場合も，368m $\mu$ および $457 \mathrm{~m} \mu$ に peak を有する chromogen を形 成し, standard MEDのそれと一致した。

\section{Alcohol-sulfuric acid chromogen spectrum}

Ethanol および硫酸を1：2の割合で混合した氷冷液を加え室温で20分放置後にその chromogen spectrum を測定した。

MNT およびMT いずれを substrate とした場合にもとの反応で強い緑色の螢光を有する黄色を呈し，そ の吸収 spectrum は Fig.5 に示すように $370 \mathrm{~m} \mu$ および $468 \mathrm{~m} \mu$ にeak があり， standard MEDのそれと 一致した。

Fig.5. Alcohol-sulfuric acid chromogen spectra of MED obtained from incubation of MNT and MT

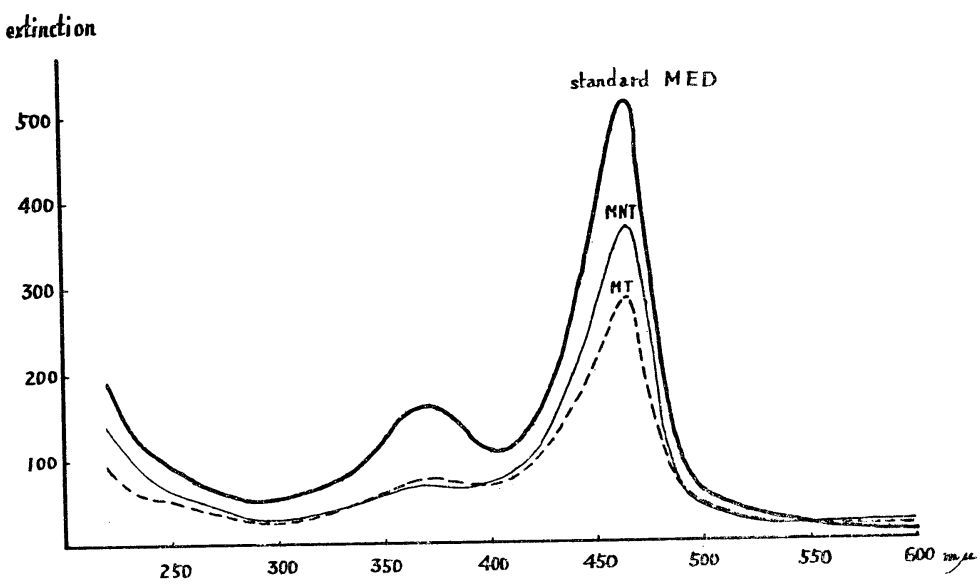

以上の成績から MNT およびMTを placental aromatizing enzyme system で incubate すれば MED が 得られるととが明らかとなつた。すなわち $17 \alpha$ 位に methyl 基をもつたままで aromatize されて MED なり，17 $\alpha$ 位の methyl 基の存在が steroid の aromatization を障害するものではないというととが出来 る.したがつて 17-substituted-19-nor steroid の aromatization の first step として前回は $\Delta^{1,4}$-double bond の形成を考慮したが，本実験はこれら steroid の aromatization に際し前述のような特殊な pathway を考える必要はないのではないかとも考えられる。

稿总終るにあたり御指導と御校閲を賜つた恩師徳田教授に深甚なる謝意总捧げ，御助言を睗つた当教室岡 田博士に謝意袁表する。また steroid 標準品の提供总いただいた帝国臓器株式会社に感謝する。 なほ本諭文の要旨は第11回日六内分必学会西日本地方会総会に和いて発表した.

\section{参 考 文 献}

1) RYAN, K.J. : J. Biol. Chem., $23: 268,(1959)$ 2 2 天津実 : 日内泌誌，38: 1164，(1963)。 3) ENGEL, L.L. : Recent Progress in Hormone Res., $5: 335,(1950) . \quad$ 4) ENGEL, L.L. et al : J. Biol. Chem., $185: 255$, (1950). $\quad$ 5) BURTON, G.M. : Nature, $170: 249$, (1952). 